FINANCIAL: Jurnal Akuntansi

Published by Program Studi Akuntansi STIE Sultan Agung Volume 5-Nomor 2, Desember 2019, (HIm 91-98)

ISSN-P: 2502-4574, ISSN-E: 2686-2581

Available online at: https://financial.ac.id/index.php/financial

\title{
DAMPAK QUICK RATIO DAN DEBT TO EQUITY RATIO TERHADAP PRICE EARNING RATIO PADA PT MERCK, TBK
}

\author{
Fiorensia $^{1)^{*}}$, Liper Siregar ${ }^{2)}$, Christine D. Nainggolan ${ }^{3)}$, Hery P. Silitonga ${ }^{4)}$ \\ ${ }^{1}$ Program Studi Akuntansi, STIE Sultan Agung, Pematangsiantar, Sumatera Utara, Indonesia \\ ${ }^{2}$ Program Studi Akuntansi, STIE Sultan Agung, Pematangsiantar, Sumatera Utara, Indonesia \\ ${ }^{3}$ Program Studi Akuntansi, STIE Sultan Agung, Pematangsiantar, Sumatera Utara, Indonesia \\ ${ }^{4}$ Program Studi Akuntansi, STIE Sultan Agung, Pematangsiantar, Sumatera Utara, Indonesia \\ "Email: ${ }^{1}$ Fiorensia.yap@gmail.com, ${ }^{2}$ liper_regar@yahoo.co.id, ${ }^{3}$ christine@ stiesultanagung.ac.id, \\ ${ }^{4}$ herysilitonga@stiesultanagung.ac.id
}

\begin{abstract}
Abstrak
Tujuan dari penelitian ini adalah untuk mengetahui gambaran Quick Ratio, Debt to Equity Ratio dan Price Earning Ratio serta pengaruh Quick Ratio dan Debt to Equity Ratio terhadap Price Earning Ratio secara simultan maupun parsial pada PT Merck, Tbk periode 2010 - 2017. Penelitian ini dilakukan dengan menggunakan metode analisis deskriptif kualitatif dan analisis deskriptif kuantitatif. Pengumpulan data dilakukan dengan metode dokumentasi. Teknik analisis data yang digunakan adalah uji asumsi klasik, analisis linear berganda, koefisien korelasi, koefisien determinasi dan uji hipotesis. Hasil penelitian ini menunjukkan bahwa Quick Ratio (QR) mengalami fluktuasi dan cenderung menurun sedangkan Debt to Equity Ratio (DER) dan Price Earning Ratio (PER) mengalami fluktuasi dan cenderung meningkat. Untuk hasil pengujian hipotesis dapat disimpulkan bahwa Quick Ratio dan Debt to Equity Ratio berpengaruh tidak signifikan terhadap Price Earning Ratio pada PT Merck Indonesia, Tbk periode 2010-2017 baik secara simultan maupun parsial.
\end{abstract}

Kata kunci: Quick Ratio (QR), Debt to Equity Ratio (DER) dan Price Earning Ratio (PER)

\section{IMPACT QUICK RATIO AND DEBT TO EQUITY RATIO OF PRICE EARNING RATIO IN PT MERCK, TBK}

\begin{abstract}
The purpose of this research was to determine the Quick Ratio, Debt to Equity Ratio and Price Earning Ratio and the influence of Quick Ratio and Debt to Equity Ratio on Price Earning Ratio simultaneously or partially at PT Merck, Tbk for the period 2010 - 2017. This research was conducted with using qualitative descriptive analysis methods and quantitative descriptive analysis. Data collection is done by the documentation method. The data analysis technique used is the classic assumption test, multiple linear analysis, correlation coefficient, coefficient of determination and hypothesis testing. The results of this study indicate that the Quick Ratio $(Q R)$ fluctuates and tends to decrease while the Debt to Equity Ratio (DER) and Price Earning Ratio (PER) fluctuate and tend to increase. For the results of hypothesis testing it can be concluded that the Quick Ratio and Debt to Equity Ratio have no significant effect on Price Earning Ratio at PT Merck Indonesia, Tbk for the period 2010 2017 both simultaneously and partially.
\end{abstract}

Keywords: Quick Ratio (QR), Debt to Equity Ratio (DER) dan Price Earning Ratio (PER)

Article History: Received: 10 Des 2019 Revised: 13 Des 2019 Accepted: 24 Des 2019 


\section{PENDAHULUAN}

Nilai perusahaan dapat dikaitkan dengan harga saham, apabila harga saham suatu perusahaan tinggi, maka makin tinggi juga nilai suatu perusahaan sehingga dapat meningkatkan kepercayaan investor kepada perusahaan tersebut. Nilai perusahaan juga dapat diukur dari berbagai aspek, salah satunya dengan menggunakan Price Earning Ratio (PER). Dengan rasio ini dapat memberi informasi kepada investor terhadap kemampuan perusahaan dalam menghasilkan laba dan kinerja masa depan perusahaan.

Nilai PER yang berfluktuasi dapat disebabkan oleh beberapa faktor diantaranya likuiditas dan leverage. Likuiditas menunjukkan kemampuan perusahaan memenuhi kewajiban jangka pendek menggunakan aset lancar dan dapat diukur dengan quick ratio sedangkan leverage merupakan kemampuan perusahaan mengukur sejauh mana aktiva perusahaan dibiayai oleh hutang dan dapat diukur dengan debt to equity ratio. Menurut Brigham dan Joel (2010), “jika rasio likuiditas, manajemen aset, manajemen utang dan profitabilitas semuanya terlihat baik dan apabila kondisi ini berjalan secara terus menerus secara stabil maka rasio nilai pasar juga akan tinggi, harga saham kemungkinan tinggi sesuai dengan yang diperkirakan".

Berikut ini adalah gambaran likuiditas yang diukur dengan Quick Ratio (QR), leverage yang diukur dengan Debt to Equity Ratio (DER), dan nilai perusahaan yang diukur dengan Price Earning Ratio (PER) pada PT Merck, Tbk yang terdaftar di Bursa Efek Indonesia tahun 2010 sampai tahun 2017.

\section{Tabel 1}

Gambaran Quick Ratio (QR), Debt To Equity Ratio (DER) dan Price Earning Ratio (PER) pada PT Merck,Tbk Periode 2010-2017

\begin{tabular}{|c|c|c|c|}
\hline Tahun & $\begin{array}{c}\text { QR } \\
\text { (kali) }\end{array}$ & $\begin{array}{c}\text { DER } \\
\text { (kali) }\end{array}$ & $\begin{array}{c}\text { PER } \\
\text { (kali) }\end{array}$ \\
\hline 2010 & 3,85 & 0,20 & 0,91 \\
\hline 2011 & 5,63 & 0,18 & 0,64 \\
\hline 2012 & 1,89 & 0,37 & 1,58 \\
\hline 2013 & 2,29 & 0,36 & 1,21 \\
\hline 2014 & 3,17 & 0,29 & 0,99 \\
\hline 2015 & 2,44 & 0,35 & 2,75 \\
\hline 2016 & 2,30 & 0,28 & 26,79 \\
\hline 2017 & 1,52 & 0,38 & 26,32 \\
\hline $\begin{array}{c}\text { Rata- } \\
\text { rata }\end{array}$ & $\mathbf{2 , 8 9}$ & $\mathbf{0 , 3 0}$ & $\mathbf{7 , 6 5}$ \\
\hline
\end{tabular}

Sumber: Laporan Keuangan PT Merck, Tbk (Data Diolah: 2019)

Dari Tabel 1 di atas dapat dilihat bahwa Quick Ratio yang menjadi parameter dari likuiditas mengalami fluktuasi dan cenderung menurun. Pada tahun 2011 QR mengalami peningkatan sebesar 5,63 kali sedangkan pada tahun 2016 mengalami penurunan sebesar 2,30. Peningkatan QR ini diikuti dengan penurunan PER, pada tahun 2011 nilai PER mengalami penurunan sebesar 0,64 kali dan pada tahun 2016 mengalami peningkatan sebesar 26,79 kali.

\section{Selanjutnya, Debt To Equity Ratio} yang menjadi parameter dari leverage mengalami fluktuasi dan cenderung meningkat. Nilai DER pada tahun 2016 mengalami penurunan sebesar 0,28 kali sedangkan penurunan nilai DER ini diikuti oleh peningkatan PER. Pada tahun 2017 DER mengalami kenaikan sedangkan PER mengalami penurunan. Nilai PER pada tahun 2016 mengalami peningkatan yang signifikan sebesar 26,79 kali. Dari penjelasan tersebut dapat disimpulkan bahwa terjadi fenomena yang tidak sejalan dengan pendapat (Brigham dan Joel 2010). 
Rumusan masalah dalam penelitian ini adalah bagaimana gambaran quick ratio, debt to equity ratio dan price earning ratio dan bagaimana dampak quick ratio dan debt to equity ratio terhadap price earning ratio pada PT Merck, Tbk baik secara simultan maupun secara parsial. Tujuan penelitian adalah untuk mengetahui gambaran quick ratio, debt to equity ratio dan price earning ratio dan bagaimana dampak quick ratio dan debt to equity ratio terhadap price earning ratio pada PT Merck, Tbk baik secara simultan maupun secara parsial.

\section{LANDASAN TEORI}

Akuntansi berisi tentang bagaimana proses pemikiran sehingga menghasilkan suatu kerangka konseptual yang terdapat prinsip, standar, metode, dan teknik, serta prosedur yang akan dijadikan landasan dalam pelaporan keuangan (Yadiati dan Ilham, 2006).

Analisis laporan keuangan terdapat dua kata, yaitu "analisis" dan laporan keuangan". Analisis adalah penguraian suatu persoalan atau permasalahan serta menjelaskan mengenai hubungan antara bagianbagian yang ada di dalamnya untuk selanjutnya diperoleh suatu pengertian secara keseluruhan. Sedangkan laporan keuangan adalah suatu penyajian terstruktur dari posisi keuangan dan kinerja keuangan suatu entitas. analisis laporan keuangan penting dilakukan untuk mengetahui kelemahan dan kekuatan pada suatu perusahaan. Informasi diperlukan untuk mengevaluasi kinerja yang dicapai manajemen perusahaan dimasa yang lalu, dan juga untuk bahan pertimbangan dalam menyusun rencana perusahaan ke depan. (Sudana : 2011)

\section{Quick Ratio}

Rasio likuiditas adalah rasio yang digunakan untuk mengetahui kemampuan perusahaan dalam memenuhi kewajiban jangka pendeknya secara tepat waktu. (Syahyunan : 2015). Salah satu proksi dari rasio likuiditas adalah Quick Ratio. Rasio ini dihitung dengan mengurangkan persediaan dari aktiva lancar dan membagi sisanya dengan utang lancar (Husnan : 2000). Quick adalah ukuran uji solvensi jangka pendek yang lebih teliti daripada rasio lancar karena pembilangnya mengeliminasi persediaan yang dianggap aktiva lancar yang sedikit tidak likuid dan kemungkinan menjadi sumber kerugian. Quick ratio memiliki ketelitian yang lebih baik dari pada current ratio, karena angka yang digunakan sebagai pembanding adalah komponen yang diyakini sangat lancar sehingga untuk mengubah menjadi kas akan berjalan dengan baik. (Fadilah, Echsan, Evalliati : 2017) Quick ratio dapat dihitung dengan rumus :

Quick Ratio $=\frac{\text { Aset Lancar }- \text { Persediaan }}{H u \tan g \text { Lancar }}$

\section{Debt To Equity Ratio}

DER adalah rasio yang digunakan untuk menilai utang dengan ekuitas. Rasio ini diperoleh dari membandingkan antara seluruh utang, termasuk utang lancar dengan seluruh ekuitas. (Kasmir: 2014) Rumusnya adalah sebagai berikut :

Debt To Equity Ratio $=\frac{\text { Total } H u \tan g}{\text { Ekuitas }}$

\section{Price Earning Ratio}

Nilai pasar menandakan sejumlah rupiah yang harus dibayarkan oleh investor untuk memperoleh satu rupiah laba perusahaan yang dilaporkan. Price Earning Ratio (PER) merupakan salah satu indikator 
yang digunakan untuk menilai harga suatu saham yang diperdagangkan di pasar modal. Price Earning Ratio (PER) menunjukkan operasi pasar terhadap kemampuan emiten, dalam menghasilkan laba (Rusdin : 2008). Bertujuan mengukur seberapa besar perbandingan antara harga saham perusahaan dengan keuntungan yang diperoleh oleh para pemegang saham (Famiah dan Siti : 2018). Rumus mengukur Price Earning Ratio (PER) adalah sebagai berikut:

Price Earning Ratio

$=\frac{H \arg \text { a Pasar per lembar saham }}{\text { Laba per Lembar saham }}$

\section{METODE}

Dalam penelitian ini, objek penelitian yang penulis gunakan adalah laporan keuangan PT Merck, Tbk selama 8 tahun terakhir yaitu dari tahun 2010 sampai dengan 2017 yang telah diaudit. Desain penelitian yang digunakan adalah penelitian kepustakaan (library research) yang menggunakan data sekunder dengan cara mengakses dari situs http://www.idx.co.id. Ruang lingkup penelitian adalah laporan keuangan PT Merck, Tbk periode 2010-2017. Variabel yang diteliti adalah Quick Ratio $\left(\mathrm{X}_{1}\right)$, Debt To Equity Ratio $\left(\mathrm{X}_{2}\right)$ dan Price Earning Ratio (Y) pada PT Merck, Tbk dari tahun 2010 sampai dengan 2017. Dalam penelitian ini, penulis menggunakan data kualitatif dan data kuantitatif. Teknik pengumpulan data adalah teknik dokumentasi dengan cara mencari data dari buku, jurnal akuntansi, surat kabar, dan dokumen-dokumen yang terkait dengan penelitian ini serta media internet dengan cara mengunduh laporan keuangan melalui situs resmi Bursa Efek Indonesia dan PT Kalbe Farma, Tbk. Teknik analisis data yang digunakan adalah uji asumsi klasik, analisis linear berganda, koefisien korelasi, koefisien determinasi dan uji hipotesis.

\section{HASIL DAN PEMBAHASAN}

\section{Gambaran Quick Ratio (QR)}

Analisis Quick Ratio (QR) pada PT Merck, Tbk periode 2010-2017 yang dijadikan sebagai objek penelitian dapat dilihat pada Tabel 2.

Tabel 2

Quick Ratio (QR) pada

PT Merck, Tbk periode 2010-2017

\begin{tabular}{|c|c|}
\hline Tahun & Quick Ratio (kali) \\
\hline 2010 & 3,85 \\
\hline 2011 & 5,63 \\
\hline 2012 & 1,89 \\
\hline 2013 & 2,29 \\
\hline 2014 & 3,17 \\
\hline 2015 & 2,44 \\
\hline 2016 & 2,30 \\
\hline 2017 & 1,52 \\
\hline Nilai Minimum & $\mathbf{1 , 5 2}$ \\
\hline Nilai Maximum & $\mathbf{5 , 6 3}$ \\
\hline Rata-rata & $\mathbf{2 , 8 8}$ \\
\hline
\end{tabular}

Sumber: Data Diolah 2019

Dari Tabel 2 menunjukkan nilai Quick Ratio (QR) PT Merck, Tbk berfluktuasi dan cenderung menurun. Hal ini disebabkan karena adanya kenaikan hutang lancar yang lebih tinggi dari kenaikan aset lancar. Nilai rata-rata Quick Ratio (QR) PT Merck, Tbk pada periode 2010-2017 sebesar 2,88 kali. Artinya setiap Rp 1 kewajiban lancar dijamin dengan $\mathrm{Rp} 2,88$ aset lancar selain persediaan.

\section{Gambaran Debt to Equity Ratio (DER)}

Analisis Debt to Equity Ratio (DER) pada PT Merck, Tbk periode 2010-2017 yang dijadikan sebagai objek penelitian dapat dilihat pada 3

Tabel 3

Debt to Equity Ratio (DER) Pada PT Merck, Tbk 
Periode 2010-2017

\begin{tabular}{|c|c|}
\hline Tahun & $\begin{array}{c}\text { Debt To Equity Ratio } \\
\text { (kali) }\end{array}$ \\
\hline 2010 & 0,20 \\
\hline 2011 & 0,18 \\
\hline 2012 & 0,37 \\
\hline 2013 & 0,36 \\
\hline 2014 & 0,29 \\
\hline 2015 & 0,35 \\
\hline 2016 & 0,28 \\
\hline 2017 & 0,38 \\
\hline Nilai Minimum & $\mathbf{0 , 1 8}$ \\
\hline Nilai Maximum & $\mathbf{0 , 3 8}$ \\
\hline Rata-rata & $\mathbf{0 , 3 0}$ \\
\hline
\end{tabular}

Sumber: Data Diolah 2019

Berdasarkan Tabel 3 terlihat bahwa nilai Debt to Equity Ratio (DER) PT Merck, Tbk berfluktuasi dan cederung meningkat, hal ini disebabkan karena kenaikan total hutang lebih tinggi dibandingkan ekuitas.

\section{Gambaran Price Earning Ratio (PER)}

Analisis Price Earning Ratio(PER) pada PT Merck, Tbk periode 2010-2017 yang dijadikan sebagai objek penelitian dapat dilihat pada Tabel 4 .

Tabel 4

Price Earning Ratio (PER) pada PT

Merck, Tbk periode 2010-2017

\begin{tabular}{|c|c|}
\hline Tahun & $\begin{array}{c}\text { Price Earning Ratio } \\
\text { (kali) }\end{array}$ \\
\hline 2010 & 0,91 \\
\hline 2011 & 0,64 \\
\hline 2012 & 1,58 \\
\hline 2013 & 1,21 \\
\hline 2014 & 0,99 \\
\hline 2015 & 2,75 \\
\hline 2016 & 26,79 \\
\hline 2017 & 26,32 \\
\hline Nilai Minimum & 0,64 \\
\hline Nilai Maximum & 26,79 \\
\hline Rata-Rata & 7,65 \\
\hline
\end{tabular}

Sumber: Data Diolah 2019

Berdasarkan Tabel 4 terlihat bahwa nilai Price Earning Ratio (PER) PT Merck, Tbk berfluktuasi dan cederung meningkat, hal ini disebabkan karena adanya kenaikan harga saham dan penurunan laba per lembar saham secara signifikan.

\section{Regresi Linear Berganda}

Analisis regresi linier berganda pada penelitian ini menggunakan SPSS 21 dengan hasil yang terlihat pada Tabel 5.

Tabel 5

\section{Analisis Regresi Linier Berganda}

\begin{tabular}{|c|c|c|c|}
\hline \multirow[t]{2}{*}{ Model } & \multicolumn{2}{|c|}{$\begin{array}{l}\text { Unstandardized } \\
\text { Coefficients }\end{array}$} & $\begin{array}{l}\text { Standardized } \\
\text { Coefficients }\end{array}$ \\
\hline & B & $\begin{array}{l}\text { Std. } \\
\text { Error }\end{array}$ & Beta \\
\hline (Constant) & 89,133 & 56,313 & \\
\hline QR & $-12,346$ & 7,159 & $-1,400$ \\
\hline DER & $-152,202$ & 122,068 & $-1,012$ \\
\hline
\end{tabular}

Sumber: Hasil Pengolahan Data SPSS 21: 2019

Berdasarkan tabel 5, model persamaan regresi yang diperoleh adalah sebagai berikut:

$$
\hat{\mathbf{Y}}=\mathbf{8 9}, 133-\mathbf{1 2}, \mathbf{3 4 6}_{\mathbf{1}} \mathbf{- 1 5 2 , 2 0 2 \mathrm { X } _ { \mathbf { 2 } }}
$$

Artinya, Quick Ratio dan Debt to Equity Ratio berpengaruh negatif terhadap Price Earning Ratio pada PT Merck, Tbk Periode 2010-2017.

\section{Koefisien Korelasi dan Determinasi}

Nilai koefisien korelasi menunjukkan seberapa besar korelasi atau hubungan antara variabel-variabel independen dengan variabel dependen. Sementara koefisien determinasi menunjukkan kemampuan variabel independen menjelaskan variasi perubahan pada variasi dependennya. Berikut hasil pengolahan data yang menunjukkan koefisien korelasi dan determinasi pada Tabel 6.

\section{Tabel 6}

Koefisien Korelasi dan Determinasi

\begin{tabular}{|l|r|r|r|r|}
\hline Model & $\mathrm{R}$ & $\mathrm{R}$ Square & $\begin{array}{l}\text { Adjusted } \\
\text { R Square }\end{array}$ & $\begin{array}{r}\text { Std. Error of } \\
\text { the Estimate }\end{array}$ \\
\hline 1 &, $644^{\mathrm{a}}$ &, 414 &, 180 & 10,58146 \\
\hline
\end{tabular}

Sumber: Hasil Pengolahan Data SPSS 21: 2019

Dari tabel 3.5terlihat terdapat hasil nilai $\mathrm{r}$ adalah 0,644 artinya terdapat 
korelasi atau hubungan yang kuat antara variabel Quick Ratio dan Debt to Equity Ratio dengan Price Earning Ratio pada PT Merck, Tbk periode 2010-2017. Sedangkan koefisien determinasi $(\mathrm{R})=$ 0,414, artinya Quick Ratio dan Debt to Equity Ratio dapat menjelaskan Price Earning Ratio sebesar $41,4 \%$ sedangkan sisanya sebesar $58,6 \%$ dapat dijelaskan oleh faktor lain yang tidak dijelaskan dalam penelitian ini seperti kebijakan dividen, struktur modal, dan profitabilitas.

\section{Pengaruh Quick Ratio (QR) dan Debt} To Equity Ratio (DER) terhadap Price Earning Ratio (PER)

Adapun uji simultan disajikan dalam tabel 7 sebagai berikut:

Tabel 7

Perkiraan Uji $\mathbf{F}_{\text {hitung }}$

\begin{tabular}{|l|r|c|c|c|}
\hline Model & df & $\begin{array}{c}\text { Mean } \\
\text { Square }\end{array}$ & F & Sig. \\
\hline Regression & 2 & 198,162 & 1,770 &, $262^{\mathrm{b}}$ \\
1 Residual & 5 & 111,967 & & \\
\multicolumn{1}{|l|}{ Total } & 7 & & & \\
\hline
\end{tabular}

Sumber: Hasil Pengolahan Data SPSS 21: 2019

Berdasarkan Tabel 7, hasil uji $\mathrm{F}$ menunjukkan bahwa nilai $F_{\text {hitung }}$ sebesar 1,770 dengan tingkat signifikansi 0,262 yang lebih besar dari 0,05 atau 0,262 > 0,05 , sedangkan nilai $\mathrm{df}=(\mathrm{n}-\mathrm{k}-1)=8-2-1$ $=5$, jika dilihat pada tabel uji $\mathrm{F}$ maka hasilnya sebesar 5,79. Karena $F_{\text {hitung }}<F_{\text {tabel }}$ $(1,770<5,79)$ maka $\mathrm{H}_{0}$ diterima yang berarti Quick Ratio dan Debt to Equity Ratio berpengaruh tidak signifikan terhadap Price Earning Ratio pada PT Merck, Tbk periode 2010-2017.

Uji $t$ berguna untuk menentukan diterima atau ditolaknya hipotesis, pengujian hipotesis dilakukan untuk mengetahui pengaruh dari Quick Ratio dan Debt to Equity Ratio terhadap Price Earning Ratio. Hasil uji t dalam penelitian ini dapat dilihat pada Tabel 8 .

\begin{tabular}{|c|c|c|c|}
\hline & Perkiraa & $\begin{array}{l}\text { I } 8 \\
\text { ai Uji t } \\
\text { ents }^{\mathbf{a}}\end{array}$ & \\
\hline & Model & $\mathrm{t}$ & Sig. \\
\hline & (Constant) & 1,583 &, 174 \\
\hline 1 & QR & $-1,725$ & ,145 \\
\hline & DER & $-1,247$ & ,268 \\
\hline
\end{tabular}

Sumber: Hasil Pengolahan Data SPSS 21: 2019

\section{Pengaruh Parsial Quick Ratio (QR) terhadap Price Earning Ratio (PER)}

Quick Ratio (QR) sebagai parameter dari likuiditas memiliki nilai $t_{\text {hitung }} 1,725<\mathrm{t}_{\text {tabel }}$ sebesar 2,57058 dan nilai signifikansi $0,145>0,05$ maka $\mathrm{H}_{0}$ diterima, artinya quick ratio berpengaruh tidak signifikan terhadap price earning ratio pada PT Merck, Tbk periode 2010-2017. Hal ini sejalan dengan penelitian yang dilakukan oleh Suliyanti (2017).

Hal ini menunjukkan bahwa Quick Ratio (QR) belum mampu mempengaruhi harga saham yang telah dibagikan dengan laba per lembar saham. Hal ini disebabkan karena persediaan rekening yang paling lama untuk berubah menjadi kas (yaitu harus melewati bentuk piutang terlebih dahulu) dan tingkat kepastian nilainya rendah (Suliyanti : 2017)

\section{Pengaruh Parsial Debt To Equity Ratio (DER) terhadap Price Earning Ratio (PER)}

Debt to Equity Ratio (DER) sebagai parameter leverage memiliki nilai $\mathrm{t}_{\text {hitung }} 1,247<\mathrm{t}_{\text {tabel }}$ sebesar 2,57058 dan nilai signifikansi $0,268>0,05$ maka $\mathrm{H}_{0}$ diterima, artinya debt to equity ratio 
berpengaruh tidak signifikan terhadap price earning ratio pada PT Merck, Tbk periode 2010-2017. Hasil ini sesuai dengan penelitian yang dilakukan oleh Firdaus (2019). Debt to equity ratio (DER) yang tinggi mengindikasikan risiko perusahaan relatif tinggi karena perusahaan mempunyai tanggungjawab yang lebih besar untuk melunasi kewajiban kepada pihak ketiga. Hal tersebut sesuai dengan yang dikemukakan oleh Langlang (dalam Firdaus : 2019), DER menunjukan bahwa struktur modal lebih banyak memanfaatkan hutang dibanding dengan ekuitas, semakin besar DER mencerminkan solvabilitas perusahaan semakin rendah, sehingga kemampuan perusahaan untuk membayar hutanghutangnya rendah. Akan tetapi para investor, terutama investor risk taker, tidak lagi beranggapan bahwa penambahan hutang akan menambah risiko pada perusahaan. Kondisi ini mengindikasikan besar kecilnya hutang yang dimiliki perusahaan tidak terlalu diperhatikan oleh investor, karena investor lebih melihat cara pihak manajemen perusahaan menggunakan dana tersebut dengan efektif dan efisien untuk mencapai nilai tambah bagi perusahaan.

\section{SIMPULAN DAN SARAN}

\section{Simpulan}

Simpulan dari penelitian ini adalah Nilai rata-rata Quick Ratio (QR) PT Merck Indonesia, Tbk pada Periode 2010-2017 mengalami fluktuasi dan cenderung menurun. Selanjutnya nilai rata-rata $D e b t$ to Equity Ratio (DER) PT Merck, Tbk pada Periode 2010-2017 berfluktuasi dan cenderung meningkat. Sedangkan nilai rata-rata Price Earning Ratio (PER) PT Merck, Tbk pada Periode 2010-2017 berfluktuasi dan cenderung meningkat. Hasil persamaan regresi linier berganda menunjukkan bahwa Quick Ratio dan Debt to Equity Ratio berpengaruh negatif terhadap Price Earning Ratio pada PT Merck, Tbk pada Periode 2010-2017. Hasil uji koefisien korelasi (r) menunjukkan bahwa hubungan antara Quick Ratio dan Debt to Equity Ratio dengan Price Earning Ratio berada di tingkat yang kuat. Sedangkan uji koefisien determinasi didapatkan hasil bahwa Quick Ratio dan Debt to Equity Ratio dapat menjelaskan Price Earning Ratio sebesar 41,4\% sedangkan sisanya sebesar $58,6 \%$ dapat dijelaskan oleh faktor lain yang tidak dijelaskan dalam penelitian ini seperti kebijakan dividen, struktur modal, profitabilitas.

Untuk uji hipotesis baik secara simultan maupun parsial menunjukkan bahwa Quick Ratio dan Debt to Equity Ratio berpengaruh tidak signifikan terhadap Price Earning Ratio pada PT Merck, Tbk pada Periode 2010-2017.

\section{Saran}

Saran yang dapat diberikan penulis adalah Untuk mencapai likuiditas yang optimal, perusahaan sebaiknya mempercepat perputaran piutang sehingga dapat meningkatkan kas karena berpengaruh terhadap nilai perusahaan. Untuk mengoptimalkan nilai DER sebaiknya perusahaan lebih meningkatkan pertumbuhan pejualan agar memperkecil kemungkinan resiko yang akan terjadi dan peminjaman utang untuk kegiatan perusahaan diusahakan tidak lebih besar dari nilai ekuitas. Untuk meningkatkan Price Earning Ratio sebaiknya perusahaan meningkatkan kinerja perusahaannya dengan maksimal. Kinerja perusahaan 
yang meningkat dapat meningkatkan nilai perusahaan.

\section{DAFTAR PUSTAKA}

Brigham, Eugene F. dan Joel F. Houston. 2010. Dasar-Dasar Manajemen Keuangan. Edisi 11. Jakarta: Salemba Empat.

Fadilah, Nurul. Echsan Ghani, Ealiati Amaniyah. (2017). Pengaruh Quick Ratio, Inventory Turnover Dan Debt To Equity Ratio Terhadap Rentabilitas Pada Perusahaan Kabel Yang Terdaftar Di Bursa Efek Indonesia. Universitas Trunojoyo Madura. Kompetensi, Vol 11, No. 1 April 2017

Famiah, Rizky. Siti, Ragil Handayani. (2018). Pengaruh Return On Equity (ROE), Debt To Equity Ratio (DER), dan Total Asset Turnover (TATO) Terhadap Price Earning Ratio (PER) (Studi Pada Perusahaan Sub Sektor Makanan Dan Minuman Yang Terdaftar Pada Bursa Efek Indonesia (BEI) Periode 2011-2016). Jurnal Administrasi Bisnis (JAB) Vol. 65. No. 1 Desember 2018.

Firdaus, Iwan dan Ika. (2019). Pengaruh Current Ratio, Debt To Equity Ratio Dan Return On Assets Terhadap Price Earning Ratio (Studi Kasus pada Sub Sektor Konstruksi dan Bangunan yang Terdaftar di Bursa Efek Indonesia Tahun 2012-2017). Jurnal Ilmiah Manajemen Bisnis, Volume 5, No. 2, Juli 2019.

Husnan, Suad. (2000). Manajemen Keuangan Teori dan Penerapan. Yogyakarta : BPFE.

Kasmir. (2014). Analisis Laporan Keuangan. PT. Raja Grafindo Persada. Jakarta.

Maith, Hendry Andres (2013). Analisis Laporan Keuangan dalam Mengukur Kinerja Keuangan Pada PT. Hanjaya Mandala Sampoerna Tbk. Jurnal EMBA vol.1 no.3 September 2013, hal. 619-628.
Rudianto. (2012). Pengantar Akuntansi, Konsep dan Teknik Penyusunan Laporan Keuangan, Adaptasi IFRS. Jakarta: Erlangga.

Rusdin. (2008). Pasar Modal. Bandung : Alfabeta.

Suliyanti. 2017. Pengaruh Quick Ratio, Debt To Equity Ratio, Debt To Asset Ratio Terhadap Nilai Perusahaan Pada Perusahaan Manufaktur Sub Sektor Makanan Dan Minuman Di Bursa Efek Indonesia Periode Tahun 2012-2014. Universitas Nusantara, PGRI. Kediri

Sudana, I Made. 2011. Manajemen Keuangan Perusahaan. Jakarta: Erlangga.

Yadiati, Winwin dan Ilham Wahyudi. 2006. Pengantar Akuntansi. Jakarta: Kencana Prenada Media Group.

\section{PROFIL SINGKAT}

Fiorensia, lahir di Pematangsiantar, pada tanggal 18 Januari 1998. Baru saja menyelesaikan pendidikan Sarjana Ekonomi pada Program Studi Akuntansi di STIE Sultan Agung pada tahun 2019. Liper Siregar, lahir pada tanggal 10 Juni 1965 di Natal, Pendidikan terakhir Pascasarjana Program Studi Akuntansi dari Universitas Sumatera Utara, tahun kelulusan 2011 dan tahun 2017 sampai dengan sekarang sedang melanjutkan pendidikan di Universitas Pasundan. Christine D. Nainggolan, lahir di Pematangsiantar pada tanggal 11 Desember 1986.Menyelesaikan pendidikan Magister pada Program Studi Akuntansi di Universitas Sumatera Utara pada tahun 2017. Saat ini beliau beraktivitas sebagai Dosen Tetap di STIE Sultan Agung. Hery P. Nainggolan lahir di Tanjung Pinang pada tanggal 03 Nopember 1987. Menyelesaikan pendidikan Magister pada Program Studi Akuntansi di Universitas Muhammadiyah Sumatera Utara pada tahun 2018. Saat ini beliau beraktivitas sebagai Dosen Tetap di STIE Sultan Agung. 